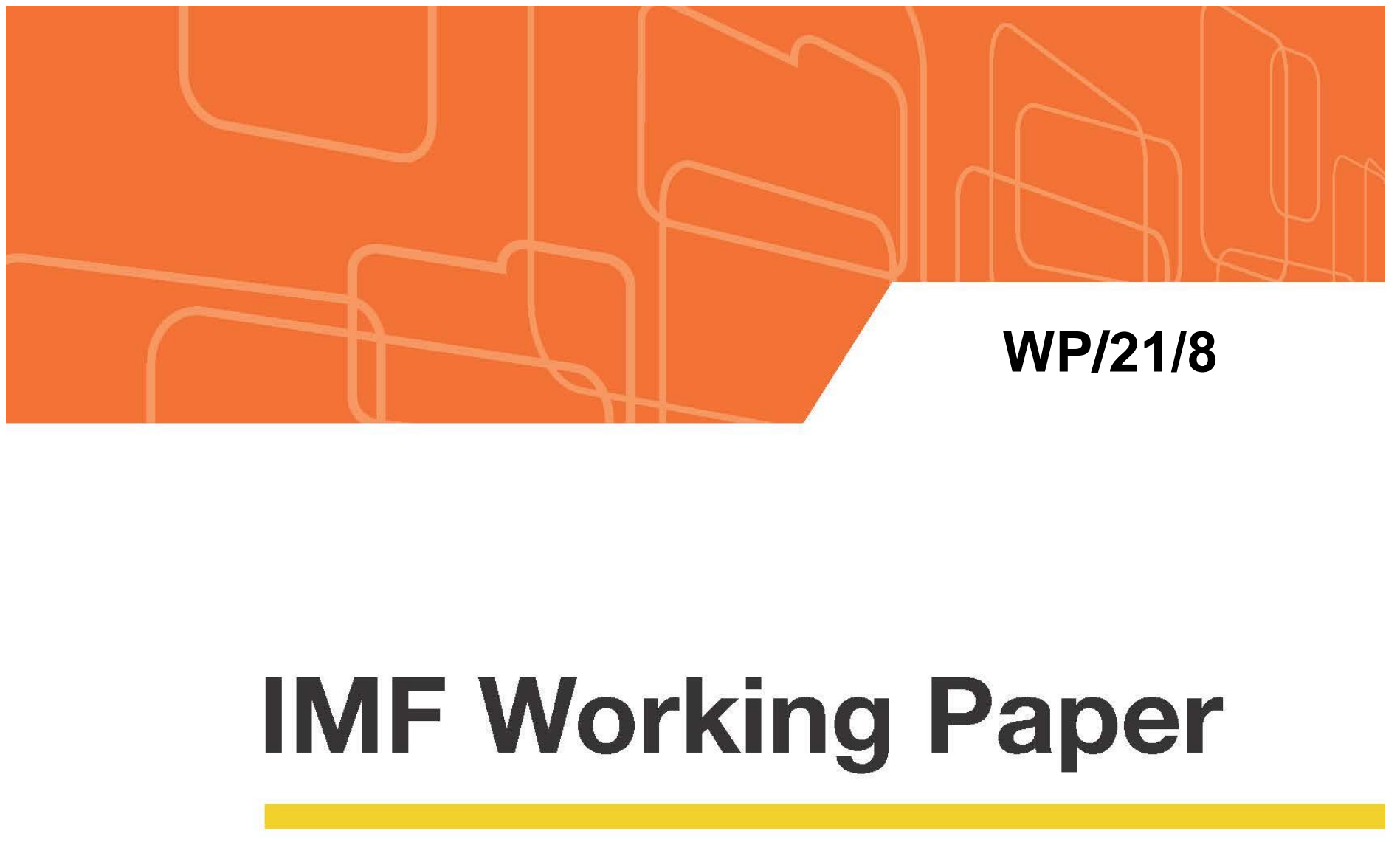

\title{
The Role of E-Government in Promoting Foreign Direct Investment Inflows
}

\author{
by Ali J. Al-Sadiq
}

IMF Working Papers describe research in progress by the author(s) and are published to elicit comments and to encourage debate. The views expressed in IMF Working Papers are those of the author(s) and do not necessarily represent the views of the IMF, its Executive Board, or IMF management. 


\title{
IMF Working Paper
}

Western Hemisphere Department

\author{
The Role of E-Government in Promoting Foreign Direct Investment Inflows \\ Prepared by Ali J. Al-Sadiq ${ }^{1}$ \\ Authorized for distribution by Nicole Laframboise
}

January 2021

\section{IMF Working Papers describe research in progress by the author(s) and are published to elicit comments and to encourage debate. The views expressed in IMF Working Papers are those of the author(s) and do not necessarily represent the views of the IMF, its Executive Board, or IMF management.}

\begin{abstract}
The outbreak of the COVID-19 pandemic has helped accelerate the digitization of public services. The lockdown initiated by most governments to curb the spread of the coronavirus forced most public agencies to switch to online platforms to continue providing information and services to the public. It is widely recognized that information diffusion and communication technology play a large role in improving the quality of public services in terms of time, cost, and interface with the public, business, and other agencies. Potentially, egovernment could enhance a country's locational advantages and attract more Foreign Direct Investment (FDI) inflows. This hypothesis is tested empirically using an unbalanced panel data analysis for 178 host countries over the period 2003-2018. The results suggest that egovernment stimulates the inflow of FDI.
\end{abstract}

JEL Classification Numbers: F21, O30

Keywords: Foreign Direct Investment, E-government, Developing Countries

Author's E-Mail Address: aalsadiq@imf.org

\footnotetext{
${ }^{1}$ The author would like to thank Nicole Laframboise, Dannah Al-Jarbou, and Rui Xu for their very helpful comments and suggestions on the earlier version of this paper.
} 


\section{Contents}

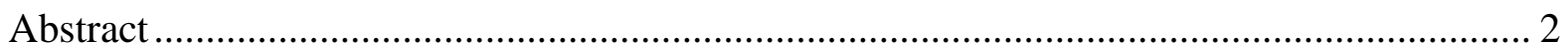

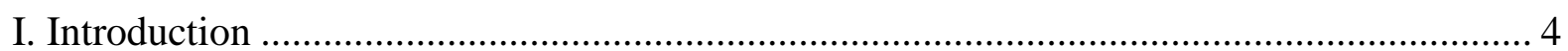

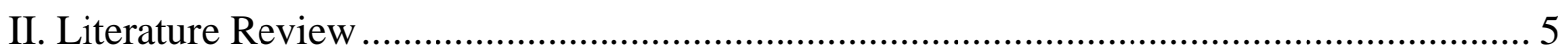

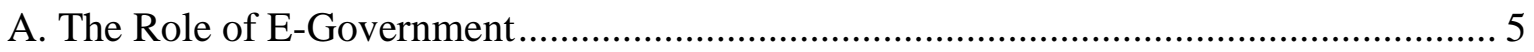

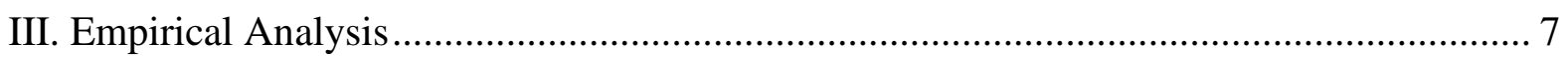

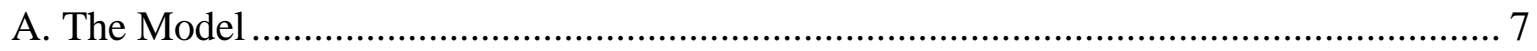

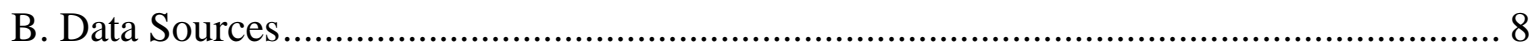

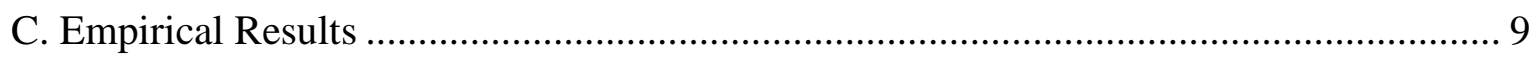

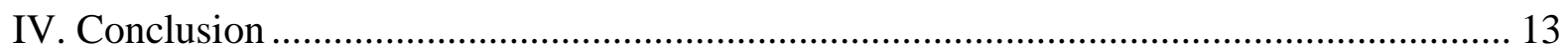

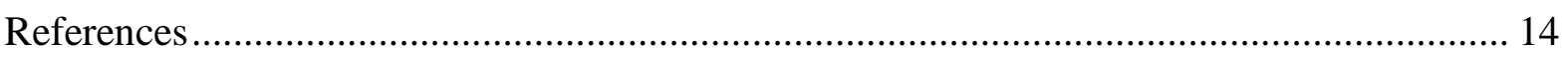

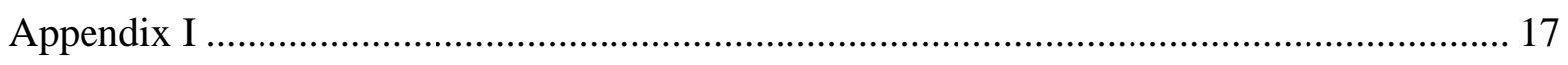

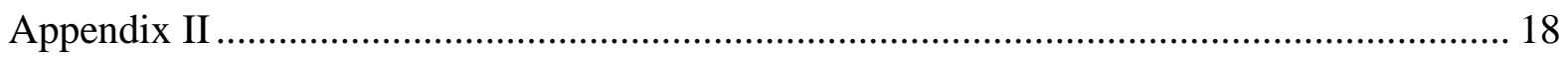




\section{INTRODUCTION}

The outbreak of the COVID-19 pandemic has played a major role in accelerating the digitization of public services globally. The lockdown initiated by most governments to curb the spread of the coronavirus forced most public agencies to switch to online platforms to continue providing routine information and services to the public. By default, this has highlighted the possibility and benefits of accelerating the digitization of public services to increase efficiency and help business and households flourish and drive economic growth.

A fundamental question in the literature on Foreign Direct Investment (FDI) is how can countries attract more FDI inflows? While the literature has identified several economic and non-economic factors that influence a country's attractiveness to FDI inflows, other locational advantages may still have an effect on the country's ability to attract more FDI. In particular, the spread of new information and communication technologies (ICTs) has reshaped the global system. There is wide recognition of the role that information diffusion and communication technology play in attracting FDI inflows (Al-Azzam and Abu-Shanab, 2014). Thus, the main question for which this study seeks to provide an empirical answer is whether the use of e-government services may help host countries remove obstacles or impediments to attracting FDI inflows into their territories.

E-government activities are designed to provide diverse public services to citizens, investors, and other agencies to conduct government operations through automated websites in a timeefficient, convenient, one-source, around the clock platform (Alfred, 2002). E-government services can improve a country's "locational" (see below) attractiveness through cost and time reductions, efficiency gains, greater transparency, and the accessibility of government information. This paper argues that improvements in e-government operations provided to public services can enhance its overall locational attractiveness and subsequently attract more FDI inflows.

No attempts have so far been made to investigate the link between the accessibility of government information and the volume of FDI a host country could receive. Therefore, the main purpose of this paper is to assess empirically the relationship between e-government and FDI inflows using data for 178 host countries, both advanced and developing, over the period 2003-2018.

The empirical results presented in this paper support the hypothesis that the presence of digital government in the form of e-government services could stimulate the inflow of FDI. Specifically, countries that implement and adopt ICTs are able to attract more FDI inflows than countries with weak ICT infrastructure. This finding is robust under different specifications and different estimation methods.

The rest of the paper is organized as follows: Section 2 presents the literature review and discusses the relationship between e-government and FDI inflows. Section 3 presents the 
model and econometric estimation method. Section 4 discuses the empirical results. The final section presents conclusions and policy implications.

\section{LiterATURE REVIEW}

According to Dunning's (1977, 1981, and 1988) "eclectic paradigm", in order for a firm to engage in FDI activities, it must first have some competitive advantages in its home country that are specific to that firm. The ownership or ' $O$ ' advantages of the firm must also be transferable to foreign markets. Conditional on the existence of the ' $\mathrm{O}$ ' advantages, there must also be certain features or characteristics of the foreign market that will allow the firm to reap the full benefits of its ' $\mathrm{O}$ ' advantages in the host country. This second set of advantages is referred to as location ' $L$ ' advantages. Finally, also conditional on the existence of ' $\mathrm{O}$ ' advantages, the firm must also possess internalization or ' $\mathrm{I}$ ' advantages, those that allow a firm to maintain its competitive position by reducing transactions costs.

The 'L' advantages answer the "where the firm locates its production facility abroad" question. Location-specific attractiveness of the potential host country plays a key role in influencing the firm's locational decision. The location-specific advantages are relative and depend on host countries' economic, social, and political factors. The implementation and adoption of ICTs such as e-government are believed to enable countries to improve their location-specific attractiveness, which in turn enable them to attract more FDI into their territories.

\section{A. The Role of E-Government}

E-government is "the use of ICT and its application by the government for the provision of information and public services to the people" (United Nations, 2004). From a theoretical perspective, e-government can enhance FDI inflows through direct and indirect channels. This paper focuses on the three main mechanisms through which e-government enhance a host county's locational advantages and subsequently attracts more FDI.

First, e-government can facilitate FDI inflows in the host country through cost and time reductions and associated efficiency gains. That is, implementing e-government services improves the effectiveness of the internal functions and processes of government services by linking different government departments and agencies into a one-stop site. Thus, providing services on-line significantly reduces the processing time and costs of various activities compared with the traditional way of handling operations. In the traditional way, an investor seeking to obtain a license to conduct business in a given country would typically spend time filling out application forms and visiting different government departments and agencies to complete the required information to obtain a license. On the other hand, the e-government model would circumvent these steps, in turn enhancing the quality of services in terms equity, accessibility of information, efficiency, and cost (Hirst and Norton (1998), cited in Valentina, 2004). For instance, in order to obtain an import or export license in Singapore prior to 1989 , applicants had to fill out 21 different forms and wait 15 to 20 days for 23 
government departments and agencies to process the request. However, after the government launched TradeNet in October 1989, only one online form was required and licenses were provided within 15 seconds (Al-Kibsi et al.,2001). ${ }^{2}$

The second way that digital government improves the provision of information and public services to people is related to how it makes governments more inclusive, effective, accountable, and transparent. The adoption of e-government services can make government more transparent to the public since it increases access to a greater range of information collected and generated by the government (Valentina, 2004). Thus, e-government can be an effective tool to fight corruption, such as bribes for acquiring business permits. For example, at the highest level in the Municipal Government of Seoul, Korea, concerns arose in 1998 about the existence of corruption in the issuing of local government licenses and permits. This led the government to introduce its Online Procedures Enhancement (OPEN) system in 1999 for civil applications, an anti-corruption web portal that provides citizens with a range of relevant information (Cho and Choi, 2004 and the World Bank, 2001). Thus, egovernment services helped to reduce corruption and red tape, which in turn helped investors become more competitive (Vindo, 2005).

The third key channel is by increasing access to information and knowledge about investment opportunities in the targeted host countries. Azubuike (2006) argues that egovernment enhances an investor's knowledge of the behaviors and operations of institutions in the target host economy. In international trade literature, distance between two countries is negatively associated with the volume of trade between them. However, in FDI literature, greater distance between two countries introduces information asymmetry, which is considered an indirect barrier to investment (Bekaert 1995). Physical distance between the source and host countries is taken into account in the investment "location" decision since it increases transport and communication costs. For instance, Portes and Rey (2005) examine bilateral international equity flows in 14 countries and find that informational friction is a major determinant of asset flows and distance between the home and host countries, used as a proxy of information asymmetries, is found to impede portfolio diversification internationally.

From an empirical perspective, Addison and Heshmati (2003) suggest that the spread of Information Technology (IT) is one of the new international determinants of FDI to developing countries. Using the number of phones per 1,000 people in the host country as a proxy for the IT infrastructure, they find evidence that IT increases FDI to developing countries. Gani and Sharma (2003), using data on high-income countries, reached the same conclusion. IT achievement and diffusion, such as mobile phones and internet hosts, are among major factors in stimulating the inflows of FDI. Choi (2003) argues that foreign

\footnotetext{
${ }^{2}$ Several studies argue that information technology (IT) has significant potential to contribute to efficiency gains and cost reductions for private sectors (Tapscott, 1996; Amit and Zott, 2001; Malhotra, 2001).
} 
investors may be attracted to countries with more internet availability. Well-established internet infrastructure improves productivity by lowering search cost and entry barriers. Reynolds et al. (2004) assess whether the level of telecommunications infrastructure in the host country is a determining factor in attracting FDI. A significant positive linkage is found between telecommunication and FDI. Other empirical studies find that e-government has a negative impact on corruption while promoting economic growth (Majeed (2020) and Machova et al., (2018)).

This study complements the literature on the effects of the accessibility of government information on FDI location. It distinguishes itself from the existing literature in using a new index for e-government which incorporates a country's official online presence, evaluates its telecommunications infrastructure, and assesses its human development capacity.

\section{EMPIRICAL ANALYSIS}

\section{A. The Model}

In order to evaluate empirically the role of government information accessibility in the host country on the volume of FDI inflows, an unbalanced panel data analysis is applied. The FDI equation is built in the following linear form:

$$
\log (F D I / P o P)_{i, t}=\beta_{o}+\beta_{1}(E-G o v)_{i, t}+x^{\prime}{ }_{i, t} \beta+\eta_{i}+\varepsilon_{i, t}
$$

Where $(i)$ is the country subscript, $(\mathrm{t})$ is time subscript, $(\beta) \mathrm{s}$ are unknown parameters to be estimated, $x_{i}$, is a set vector of explanatory variables chosen to control for individual country specific characteristics and is based upon related existing empirical work, $(\eta)$ is timeinvariant country-specific factors, and $(\varepsilon)$ is the random disturbance term. The main objective of this empirical exercise is to estimate the sign and magnitude of $(\beta 1)$, i.e., the marginal effect of e-government on FDI inflows. The effects of the control variables are the secondary interests of this study. The dependent variable is total FDI inflows received by a host country (i) at time $(t)$ divided by the host country's total population, i.e., FDI per capita.

The key independent variable is the E-Gov index scale in the host country which aims to repreasent the capacity of a country to deliver online information and services. The UN's EGovernment Development Index (EGDI) was first created in 2003 and has been updated as part of the bi-annual E-government Survey published by the United Nations Department of Economic and Social Affairs. The EGDI, is a survey composite index based on a weighted average of three normalized indices: (1) the Online Service Index, (2) the Telecommunication Infrastructure Index (TII), and (3) the Human Capital Index (HCI). The index ranges from 0 -zero readiness to adopt or implement e-government activities-to 1 , a full level of readiness (see Appendix I for further discussion on this index). Denmark, followed by the Republic of Korea, and Estonia, lead the world in providing government services and information through the internet, according to the 2020 EGDI. The remaining countries in the top 10 are Finland, Australia, Sweden, United Kingdom, New Zealand, the 
U.S., Netherlands, Singapore, Iceland, Norway, and Japan. Among developing countries, Bhutan, Bangladesh and Cambodia have become leaders in digital government development, advancing from the middle to the high EGDI group in 2020. Geographically by region, in 2020 Europe (0.82) continues to lead with the highest regional EGDI, followed by Asia (0.64), the Americas (0.63), Oceania (0.51) and finally Africa (0.39).

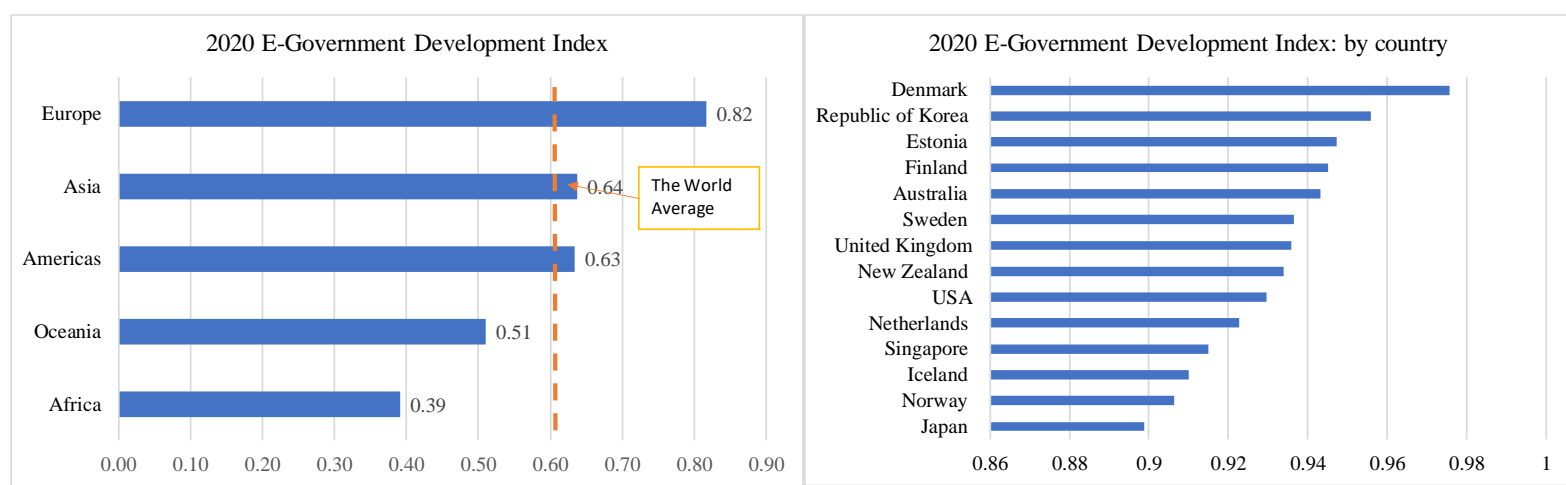

Source: the United Nations' e-Government Knowledgebase

The choice of control variables is motivated by the related existing empirical studies and data availability. We control for the host countries' level of development and market potential as measured by their GDP per capita, GDP growth rate, and population growth, respectively. We expect that FDI inflows are positively associated with these factors. The degree of openness to international trade is measured by total exports and imports as a percentage of GDP, whose effect is also expected to be positive. Macroeconomic instability is controlled by the inflation rate in host countries where a negative relationship is expected since high inflation causes uncertainty and instability. In addition, the rule of law is included as a general measure of institutional quality, corruption, and political stability.

\section{B. Data Sources}

We employ an unbalanced panel data for 178 developed and developing countries over the period 2003-2018. Data on FDI inflows and macroeconomic variables come from the World Bank's World Development Indicators (WDI, 2020). Data on institutional quality and corruption come from the International Country Risk Guide (ICRG). Data on political risk come Gibney et al., (2020) and data on e-government are based on the UN's EGDI. Details and sources of the data used are presented in Appendix II. Appendix Tables 1, 2, and 3 present the descriptive statistics, correlation matrix, and the list of sample countries, respectively. As shown in the Appendix Table 1, there are considerable variations in the EGov index across-countries, ranging from 0.07 in Central African Republic to 0.88 in the U.S. Moreover, there is a positive correlation between the country's income level and its egovernment development index. 


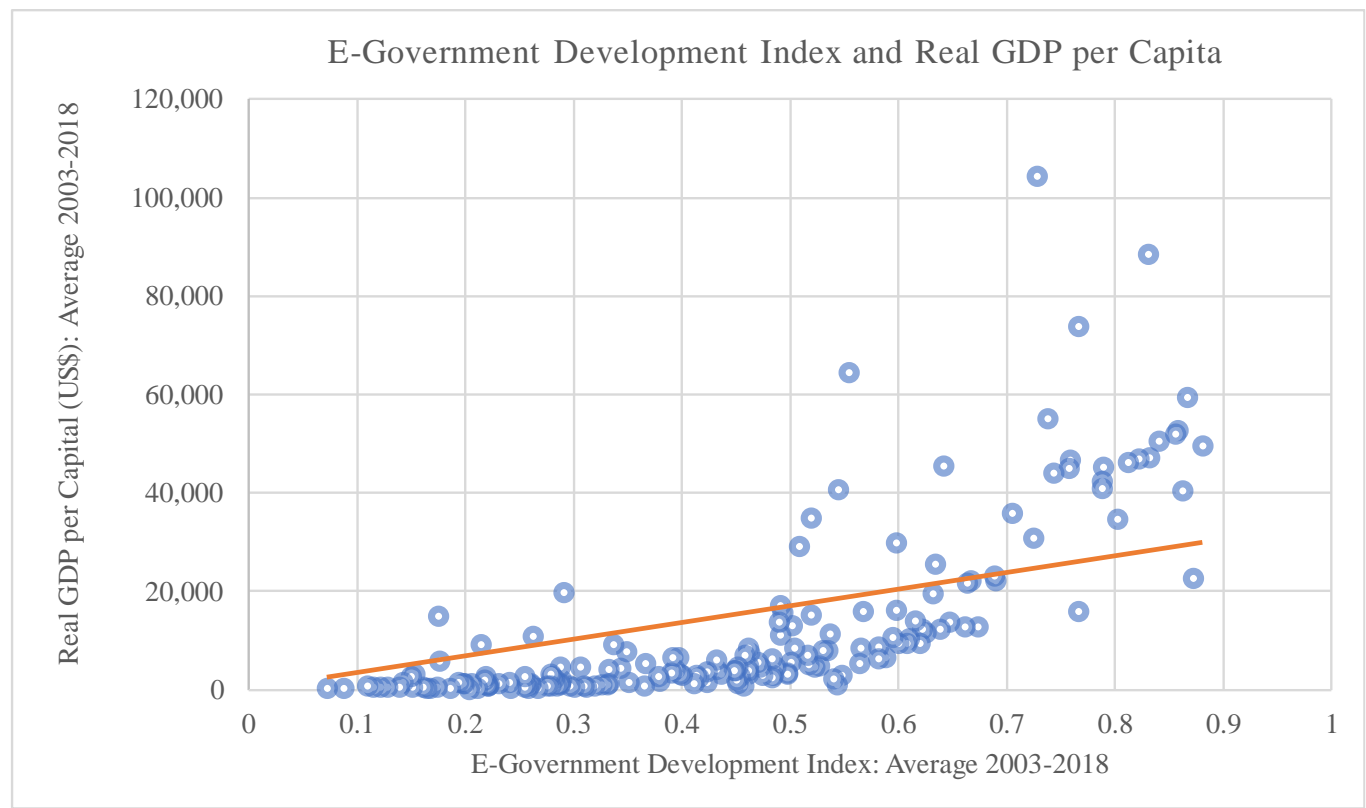

Source: Author's calculations. Data on real GDP per capita come from WDI, 2020 and data on E-government index come from the UN's EGDI

\section{Empirical Results}

The model described above is estimated by a means of Fixed Effects to control for time invariant country-specific factors. The regression results are presented in Table 1. Six different regressions are run: Model (1) employs the full sample of developed and developing countries; Model (2) reports the results after adding the quality of institutions, corruption, and political risk variables into Model (1); Model (3) estimates the model for a sample containing only developing countries (excluding the high-income OECD countries); Model (4) reports the results after adding the quality of institution, corruption, and political risk variables into Model (3); and Models (5) and (6) estimate the model for a sample containing developing countries after excluding small states.

As can be seen from the results presented under column (1), the coefficient of the egovernment variable is positive and significant at the 1.0 percent level, suggesting that the accessibility of government information on-line stimulates FDI inflows. Thus, ceteris paribus, countries with high levels of ICTs over the period 2003-2018 have received more FDI inflows. The results are robust even after controlling for other factors, as seen from column (2). Since Blonigen and Wang (2004) find that the factors that determine the location of FDI inflows vary systematically across developed and developing countries, developed countries are excluded from the sample and separate regressions were run including only developing countries. The results presented in columns (3)-(6) show that the empirical results are not sensitive to the sample specifications and thus reach the same conclusion. 
Table 1: E-Government and FDI Inflows

Dependent Variable: log of FDI inflows per captia: 2003-2018

Independent Variables

Full Sample

Developing Countries

(1)

(2)

(3)

(4)

(5) $1 /$

(6) $1 /$

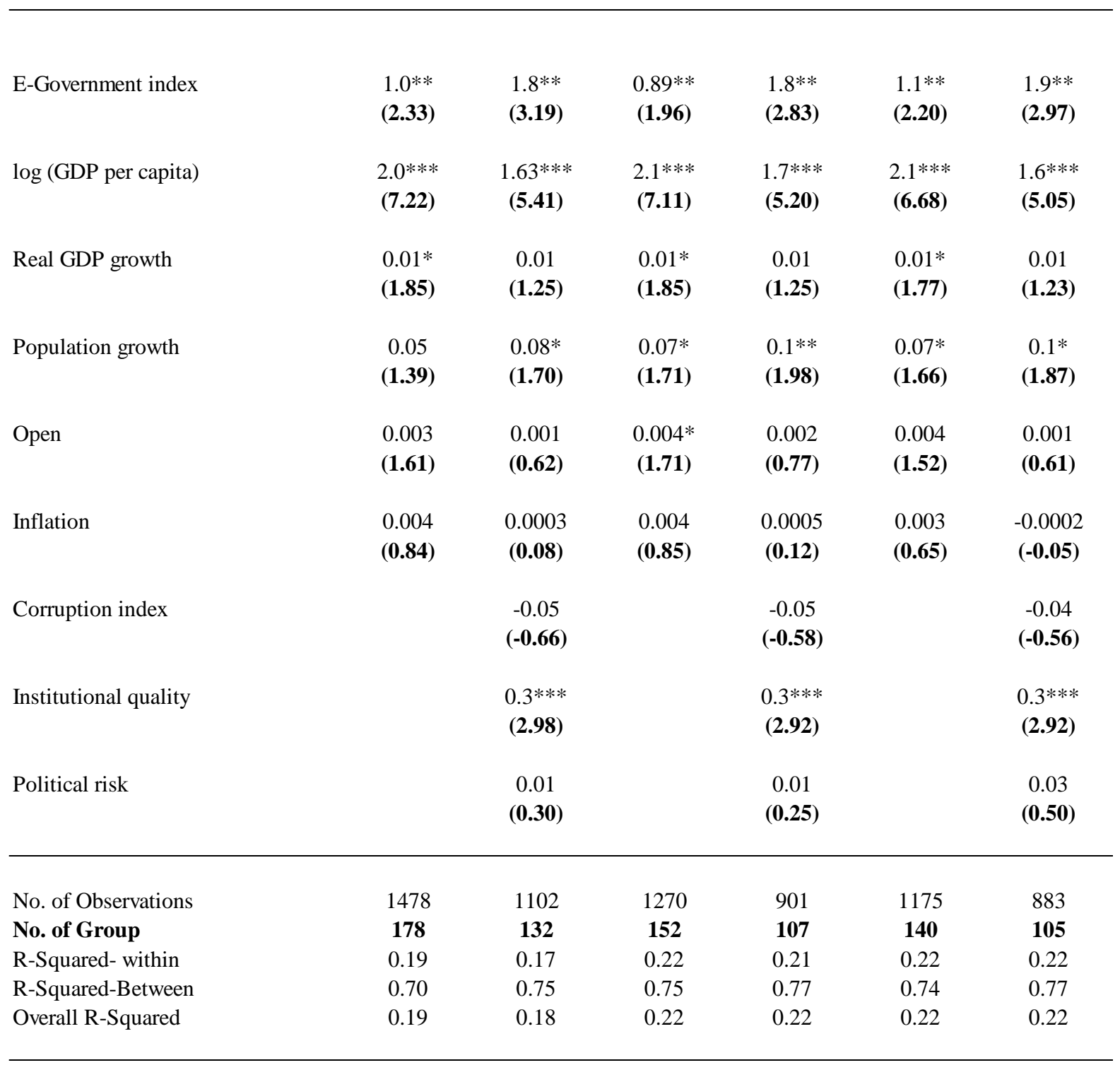

\section{Notes}

1/ Excluding small states.

2/ All regressions include a constant term and are estimated by Fixed Effects Model.

$3 /$ Robust t-values are in parentheses. $* * * * *$ and $*$ indicate statistical significance at 1 percent, 5 percent and 10 percent levels, respectively. 
With the exception of the coefficients produced for inflation and political risk, which have the opposite sign, all the control variables have the expected effects and are consistent with the literature of the determinants of FDI location. The host country's level of development is positive and highly significant at the 1.0 percent level in all models. The growth rate of GDP and population, which are proxies for market potential, are also positive, implying that foreign investors are forward looking. The degree of openness to international trade is also positive but insignificant in all models. the estimated coefficients on the quality of institutions are positive and statistically significant in all models while corruption and political risk are found to be insignificant in all models.

The above results suggest that e-government services enhance FDI inflows. To evaluate our results, we undertake a further check in order to come to a conclusion on the effects of egovernment by exploring alternative estimation methods. Two different estimation methods; namely Pooled OLS (POLS) and the Random Effects (RE) model are considered. These two methods mainly differ in the treatment of the intercept term. POLS assumes that the intercept term is constrained to be equal across groups, and so the POLS is unbiased, consistent and efficient (Greene, 2003: p. 285). ${ }^{3}$ The RE model assumes that the individual effect is itself a random variable rather than being a fixed constant, composed of a common mean and a random element to each cross-section. Thus, in this case, the individual effect is assumed to be uncorrelated with the explanatory variables. In the RE model, the individual and possibly time effects are combined with the $(\varepsilon)$ term to create a composite error term. As this composite error term is typically non-spherical, a Generalized Least Squares (GLS) approach is required. The benefit of this approach is that there are fewer parameters to estimate. Yet the RE model is more efficient than the Fixed Effects model only if the individual effects are uncorrelated with the independent variables (Greene, 2003: p. 293).

Equation (1) is re-estimated using those two estimators. The results are reported in Table 2: the significance of the E-Gov index on FDI inflows remains consistent in all the alternative specifications.

\footnotetext{
${ }^{3}$ The Fixed Effects (FE) model allows some heterogeneity across cross-sectional groups in pooled data and so the FE model assumes that the individual effects vary across-groups but are the same over time within a given group. One advantage of using the FE model is that we can control for unobservable individual-specific fixed effects (Greene, 2003: p. 285). On the other hand, with the FE model it is not possible to incorporate time invariant variables thus significant degrees of freedom are lost (Baltagi, 2005: p. 13).
} 
Table 2: Alternative Estimators: E-Government and FDI Inflows

Dependent Variable: log of FDI inflows per captia: 2003-2018

\begin{tabular}{|c|c|c|c|c|c|c|}
\hline \multirow{2}{*}{ Independent Variables } & \multicolumn{3}{|c|}{ Pooled OLS } & \multicolumn{3}{|c|}{ Random Effects Model } \\
\hline & (1) & (2) & (3) & (1) & (2) & (3) \\
\hline E-Government index & $\begin{array}{c}0.7^{*} \\
(\mathbf{2 . 2 6})\end{array}$ & $\begin{array}{l}1.3 * * * \\
(\mathbf{3 . 6 6 )}\end{array}$ & $\begin{array}{l}1.7 * * * \\
(4.95)\end{array}$ & $\begin{array}{l}1.8 * * * \\
(\mathbf{4 . 3 9 )}\end{array}$ & $\begin{array}{l}2.0^{* * * *} \\
(\mathbf{4 . 6 7 )}\end{array}$ & $\begin{array}{l}2.2 * * * \\
(\mathbf{5 . 3 0})\end{array}$ \\
\hline $\log$ (GDP per capita) & $\begin{array}{l}0.7 * * * \\
(\mathbf{1 6 . 1 9 )}\end{array}$ & $\begin{array}{l}0.8^{* * * *} \\
\mathbf{( 1 5 . 3 0 )}\end{array}$ & $\begin{array}{l}0.7 * * * \\
(\mathbf{1 4 . 6 0 )})\end{array}$ & $\begin{array}{c}0.8^{* * * *} \\
(\mathbf{9 . 1 8})\end{array}$ & $\begin{array}{c}0.8^{* * * *} \\
(\mathbf{8 . 6 6 )}\end{array}$ & $\begin{array}{c}0.7 * * * \\
(\mathbf{8 . 6 1})\end{array}$ \\
\hline Real GDP growth & $\begin{array}{c}0.01 \\
(\mathbf{0 . 9 1})\end{array}$ & $\begin{array}{c}0.01 \\
(\mathbf{0 . 9 3})\end{array}$ & $\begin{array}{c}0.01 \\
\mathbf{( 1 . 0 7 )}\end{array}$ & $\begin{array}{c}0.01 \\
(\mathbf{1 . 0 9})\end{array}$ & $\begin{array}{c}0.01 \\
(\mathbf{1 . 1 6})\end{array}$ & $\begin{array}{c}0.01 \\
(\mathbf{1 . 1 4})\end{array}$ \\
\hline Population growth & $\begin{array}{l}0.05^{* *} * \\
(\mathbf{2 . 5 8})\end{array}$ & $\begin{array}{l}0.05 * \\
\mathbf{( 2 . 5 1 )}\end{array}$ & $\begin{array}{c}0.06 * * \\
(\mathbf{2 . 9 6 )}\end{array}$ & $\begin{array}{c}0.09 * * \\
(\mathbf{3 . 2 6})\end{array}$ & $\begin{array}{c}0.09 * * * \\
\mathbf{( 3 . 5 5 )}\end{array}$ & $\begin{array}{c}0.09 * * * \\
\mathbf{( 3 . 5 1 )}\end{array}$ \\
\hline Open & $\begin{array}{c}0.01 * * * \\
\mathbf{( 1 3 . 2 4 )}\end{array}$ & $\begin{array}{c}0.01 * * * \\
(\mathbf{8 . 7 0})\end{array}$ & $\begin{array}{c}0.01 * * * \\
(\mathbf{8 . 9 7})\end{array}$ & $\begin{array}{c}0.01 * * * \\
\mathbf{( 4 . 1 0 )}\end{array}$ & $\begin{array}{l}0.01 * \\
(\mathbf{2 . 4 4 )}\end{array}$ & $\begin{array}{l}0.01 * \\
(\mathbf{2 . 5 3})\end{array}$ \\
\hline Inflation & $\begin{array}{l}-0.002 \\
\mathbf{( - 0 . 3 6 )}\end{array}$ & $\begin{array}{l}-0.003 \\
\mathbf{( - 0 . 2 7 )}\end{array}$ & $\begin{array}{l}-0.002 \\
\mathbf{( - 0 . 6 0 )}\end{array}$ & $\begin{array}{l}-0.002 \\
\mathbf{( - 0 . 4 7 )}\end{array}$ & $\begin{array}{l}-0.002 \\
\mathbf{( - 0 . 2 7 )}\end{array}$ & $\begin{array}{l}-0.002 \\
\mathbf{( - 0 . 5 4 )}\end{array}$ \\
\hline Corruption index & $\begin{array}{c}-0.07 \\
\mathbf{( - 1 . 5 5 )}\end{array}$ & $\begin{array}{c}-0.06 \\
\mathbf{( - 1 . 0 8 )}\end{array}$ & $\begin{array}{l}0.001 \\
(\mathbf{0 . 0 2})\end{array}$ & $\begin{array}{c}-0.02 \\
(-\mathbf{0 . 4 3})\end{array}$ & $\begin{array}{c}-0.05 \\
(-\mathbf{0 . 6 4 )}\end{array}$ & $\begin{array}{c}-0.03 \\
(-\mathbf{0 . 3 8})\end{array}$ \\
\hline Institutional quality & $\begin{array}{c}-0.02 \\
(\mathbf{- 0 . 7 4 )}\end{array}$ & $\begin{array}{c}-0.02 \\
(-\mathbf{0 . 6 5})\end{array}$ & $\begin{array}{c}-0.02 \\
(\mathbf{- 0 . 4 6 )}\end{array}$ & $\begin{array}{c}0.04 \\
(\mathbf{0 . 7 5})\end{array}$ & $\begin{array}{c}0.06 \\
(\mathbf{0 . 9 2})\end{array}$ & $\begin{array}{c}0.06 \\
(\mathbf{0 . 9 4})\end{array}$ \\
\hline Political risk & $\begin{array}{l}-0.07 * \\
\mathbf{( - 2 . 0 2 )}\end{array}$ & $\begin{array}{c}-0.11 * * \\
(-2.73)\end{array}$ & $\begin{array}{c}-0.11 * * \\
(-2.70)\end{array}$ & $\begin{array}{c}-0.01 \\
(-\mathbf{0 . 2 9})\end{array}$ & $\begin{array}{c}-0.03 \\
\mathbf{( - 0 . 6 0 )}\end{array}$ & $\begin{array}{c}-0.02 \\
(\mathbf{- 0 . 4 0 )}\end{array}$ \\
\hline No. of Observations & 1102 & 901 & 883 & 1102 & 901 & 883 \\
\hline No. of Group & 132 & 107 & 105 & 132 & 107 & 105 \\
\hline R-Squared- within & -- & -- & -- & 0.14 & 0.19 & 0.19 \\
\hline R-Squared-Between & -- & -- & -- & 0.81 & 0.80 & 0.80 \\
\hline Overall R-Squared & 0.71 & 0.67 & 0.70 & -- & -- & -- \\
\hline
\end{tabular}

\section{Notes}

1/ Excluding small states.

2/ All regressions include a constant term and are estimated by Fixed Effects Model.

3/ Robust t-values are in parentheses. ***, ** and * indicate statistical significance at 1 percent, 5 percent and 10 percent levels, respectively. 


\section{CONClusion}

While the literature on the determinants of FDI location has identified several factors (economic and non-economic) that influence a country's attractiveness to FDI, e-government could enhance a country's ability to attract more FDI into its territory. E-government has been found to play a vital role in improving the efficiency and effectiveness of internal functions and processes of government by linking different government departments and agencies into one site. This improves the flow of information among different government departments and agencies, reducing processing time and bureaucratic and inefficient approval procedures. It also makes government more inclusive, accountable, and transparent, which helps reduce red tape and the opportunity for corruption. All told, e-government can lower the costs of doing business and raise the potential return on investment, factors attractive to FDI.

The main objective of this study is to estimate empirically the impact of e-government on FDI flows into the host country's territory. Using an unbalanced panel data for 178 host developed and developing countries over the period 2003-2018, the empirical evidence presented in this study supports the hypothesis that better e-government services are correlated with higher FDI inflows.

There are many benefits to moving to digital government, including lowering costs and raising the efficiency and effectiveness of public services. The findings in this study confirm that it has important implications for attracting FDI inflows. In addition to the benefits of greater efficiency and effectiveness, it is suggested that the development of digital government services should be a top priority for countries who want to attract FDI. 


\section{REFERENCES}

Addison, T. and A. Heshmati (2003), "The New Global Determinants of FDI Flows to Developing Countries", WIDER Discussion Paper No. 2003/45, World Institute for Development Economics Research of the United Nations University.

Al-Azzam, A. and E. Abu-Shanab (2014), "E-government: The Gate for Attracting Foreign Investments", Conference: 2014 6th International Conference on Computer Science and Information Technology (CSIT), DOI: 10.1109/CSIT.2014.6805995.

Alfred, T.H. (2002), "Reinventing Local Governments and the E-Government Initiative", Public Administrations Reviews, 62(4), 434-444.

Al-Kibsi, G., De Boer, K., Mourshed, M. and Rea, P.R. (2001), "Putting Citizens Online, Not In- line", The McKinsey Quarterly.

Al-Sadig, A. (2009), "The Effects of Corruption on Foreign Direct Investment: a panel data analysis", Cato Journal, 29(2), 267-294.

Amit, R. \& Zott, C. (2001), "Value Creation in E-Business", Strategic Management Journal, 22, 493-520.

Azubuike, Abraham A. (2006), “Accessibility of Government Information as a Determinant of Inward Foreign Direct Investment in Africa", World Library and information Congress: 72nd IFLA General Conference and Council 20-24 August 2006, Seoul, Korea.

Baltagi, B., (2005), Econometric Analysis of Panel Data, 3rd edition (Hoboken, NJ: Wiley).

Bekaert, G. (1995), "Market Integration and Investment Barriers in Emerging Equity Markets", World Bank Economic Review 9(1), 75-107.

Blonigen, B., and M. Wang (2004), "Inappropriate Pooling of Wealthy and Poor Countries in Empirical FDI Studies", NBER working paper no. 10378. 
Cho, Y. H. and B. Choi (2004), "E-Government to Combat Corruption: The Case of Seoul Metropolitan Government”, International Journal of Public Administration, 27:10, 719-735.

Choi, C. (2003), "Does the Internet Stimulate Inward Foreign Direct Investment?” Journal of Policy Modeling 25, 319-326.

Dunning, J. (1977), "Trade, Location of Economic Activity and the MNE: A Search for an Eclectic Approach,” In B. Ohlin, P.O. Hesselborn and P.M. Wijkman (eds.), the International Allocation of Economic Activity, Macmillan, London: 395-415.

Dunning, J. (1981) "Explaining the International Direct Investment Position of Countries: Towards a Dynamic or Developmental Approach", Weltwirtschaftliches Archiv, 117, $30-64$.

Dunning, J. (1988), “The Eclectic Paradigm of International Production: A Restatement and Some Possible Extensions”, Journal of International Business Studies, 19, 1-29.

Gani, A. and B. Sharma (2003), "The Effects of Information Technology Achievement and Diffusion on Foreign Direct Investment", Perspectives on Global Development and Technology 2 (2), 161-178.

Gibney, M., L. Cornett, R. Wood, P. Haschke, D. Arnon, A. Pisanò, G. Barrett, and B. Park, (2020), “The Political Terror Scale 1976-2019”, Date Retrieved, from the Political Terror Scale website: http://www.politicalterrorscale.org.

Greene, W. (2003), “Econometric Analysis.” 5th ed. Upper Saddle River, N.J.: Prentice-Hall.

Hirst, P. and Norton, M. (1998), "Electronic Government. Information Technologies and the Citizen", United Kingdom Parliament Parliamentary Office of Science and Technology, http://www.parliament.uk/post/egov.htm. 
Máchová, R., J. Volejníková, M. Lněnička (2018), "Impact of E-government Development on the Level of Corruption: Measuring the Effects of Related Indices in Time and Dimensions", Review of Economic Perspective - 18 (2), pp. 99-121.

Majeed, M. (2020), “Do digital governments foster economic growth in the developing world? An empirical analysis”, Economic Research and Electronic Networking.

Malhotra, Y. (2001), "Enabling Next Generation e-Business Architectures: Balancing Integration and Flexibility for Managing Business Transformation”, Intel Corporation: Portland, $O R$.

Portes, R. and H. Rey. (2005) “The Determinants of Cross-Border Equity Flows”, Journal of International Economics 65, 269-296.

Reynolds, T., C. Kenny, J. Liu and C. Z. Qiang (2004) "Networking for Foreign Direct Investment: The Telecommunications Industry and Its Effect on Investment", Information Economics and Policy 16, 159-164

Tapscott, D. (1996), The Digital Economy, New York: McGraw Hill.

United Nations (2004), “E-Government Survey 2004: Towards Access for Opportunity”, New York, United States

United Nations (2020), "E-Government Survey 2020: Digital Government in the Decade of Action for Sustainable Development", New York, United States.

Valentina, N. (2004), "E-Government for Developing Countries: Opportunities and Challenges", EJISDC 18(1), 1-24.

Vindo, H.D. (2005), "Opening to the World: The Effect of Internet Access on Corruption”, School of Information, University of Michigan.

World Bank (2001): “Issue Note: E-Government and the World Bank”. November 5.

World Bank (2020), World Development Indicators (WDI). 


\section{APPENDIX I \\ The E-Government Development Index ${ }^{4}$}

The E-government development index (EGDI), which is used to measure the readiness and capacity of national institutions to use ICTs to deliver public services, is a survey composite index based on a weighted average of three normalized indices: (1) scope and quality of online services (Online Service Index, OSI), (2) development status of telecommunication infrastructure (Telecommunication Infrastructure Index, TII), and (3) inherent human capital (Human Capital Index, HCI).

\section{EGDI = 1/3 $($ OSI normalized + TII normalized + HCI normalized $)$}

- The Online Service Index (OSI) is a composite normalized score derived on the basis on an Online Service Questionnaire.

- The Telecommunication Infrastructure Index is an arithmetic average composite of five indicators: (i) estimated Internet users per 100 inhabitants; (ii) number of main fixed telephone lines per 100 inhabitants; (iii) number of mobile subscribers per 100 inhabitants; (iv) number of wireless broadband subscriptions per 100 inhabitants; and (v) number of fixed broadband subscriptions per 100 inhabitants.

- The Human Capital Index (TII) consists of four components, namely: (i) adult literacy rate; (ii) the combined primary, secondary and tertiary gross enrolment ratio; (iii) expected years of schooling; and (iv) average years of schooling.

Prior to the normalization of the three indices, the Z-score standardization procedure is implemented for each index to ensure that the overall EGDI is equally decided by the three component indexes. After the Z-score standardization, the arithmetic average sum becomes a good statistical indicator, where "equal weights" truly means "equal importance." For standard Z-score calculation of each component indicator:

where:

$$
\boldsymbol{Z}=\frac{(\boldsymbol{x}-\boldsymbol{\eta})}{\boldsymbol{\sigma}}
$$

$\mathbf{x}$ is a raw score to be standardized;

$\boldsymbol{\eta}$ is the mean of the sample;

$\boldsymbol{\sigma}$ is the standard deviation of the sample.

The composite value of each component index is then normalized to fall between the range of 0 to 1 and the overall EGDI is derived by taking the arithmetic average of the three component indices.

\footnotetext{
${ }^{4}$ Source: United Nations (2020): "E-Government Survey 2020: Digital Government in the Decade of Action for Sustainable Development", New York, United States.
} 


\section{APPENDIX II}

\section{Definitions of Variables and Their Sources}

\begin{tabular}{|c|c|c|}
\hline Variables & Definition & Source \\
\hline FDI inflows & Foreign direct investment inflows & $\begin{array}{l}\text { The World Bank's World development } \\
\text { Indicators, } 2020\end{array}$ \\
\hline RGDPG & Real GDP growth & $\begin{array}{l}\text { The World Bank's World development } \\
\text { Indicators, } 2020\end{array}$ \\
\hline Inflation & Annual inflation rate & $\begin{array}{l}\text { The World Bank's World development } \\
\text { Indicators, } 2020\end{array}$ \\
\hline Population & $\begin{array}{l}\text { General government gross debt as } \\
\% \text { of GDP }\end{array}$ & $\begin{array}{l}\text { The World Bank's World development } \\
\text { Indicators, } 2020\end{array}$ \\
\hline Openness & Exports and Imports as a \% of GDP & $\begin{array}{l}\text { The World Bank's World development } \\
\text { Indicators }\end{array}$ \\
\hline E-Gov Index & E-Government Development Index & The UN's e-Government Knowledgebase \\
\hline Political Risk & $\begin{array}{l}\text { Political Terror Scale-US State } \\
\text { Department, } 1 \text { (very low), and } 5 \\
\text { (very high) }\end{array}$ & http://politicalterrorscale.org/ \\
\hline $\begin{array}{l}\text { Quality of } \\
\text { Institutions }\end{array}$ & $\begin{array}{l}\text { Index measuring law and order } \\
\text { ranging from } 0 \text { (very low) to } 6 \\
\text { (very high) }\end{array}$ & $\begin{array}{l}\text { International Country Risk Guide, the } \\
\text { Political Risk Groups }\end{array}$ \\
\hline $\begin{array}{l}\text { Corruption } \\
\text { level }\end{array}$ & $\begin{array}{l}\text { Corruption level } 0 \text { (very low) to } 6 \\
\text { (very high) }\end{array}$ & $\begin{array}{l}\text { International Country Risk Guide, the } \\
\text { Political Risk Groups }\end{array}$ \\
\hline
\end{tabular}


Appendix Table 1: Descriptive Statistics

Sample: 178 host countries: 2003-2018

\begin{tabular}{lrrrrr} 
Variable & Obs & Mean & Std. Dev. & Min & Max \\
\hline Log (FDI/PoP) & 1,478 & 4.75 & 2.06 & -5.2 & 11.3 \\
$\log$ (GDP per capita) & 1,478 & 8.44 & 1.46 & 5.3 & 11.6 \\
Real GDP growth & 1,478 & 4.23 & 5.31 & -33.1 & 123.1 \\
Open & 1,478 & 88.04 & 49.19 & 0.2 & 437.3 \\
Inflation & 1,478 & 5.94 & 8.74 & -31.5 & 157.0 \\
Population growth & 1,478 & 1.49 & 1.55 & -9.1 & 16.5 \\
E-government index & 1,478 & 0.45 & 0.21 & 0.0 & 0.9 \\
Online services & 1,478 & 0.39 & 0.26 & 0.0 & 1.0 \\
Institutional quality & 1,102 & 3.65 & 1.28 & 0.5 & 6.0 \\
Corruption index & 1,102 & 3.41 & 1.14 & 0.0 & 6.0 \\
Political Risk & 1,476 & 2.44 & 1.10 & 1.0 & 5.0 \\
& & & & & \\
\hline
\end{tabular}

Source: Author's calculations

Appendix Table 2: Correlation Matrix

\begin{tabular}{|c|c|c|c|c|c|c|c|c|c|c|}
\hline Variables & 1 & 2 & 3 & 4 & 5 & 6 & 7 & 8 & 9 & 10 \\
\hline $\log$ (FDI/Pop) & 1.00 & & & & & & & & & \\
\hline E-Government index & 0.69 & 1.00 & & & & & & & & \\
\hline Online services & 0.53 & 0.91 & 1.00 & & & & & & & \\
\hline Log (GDP per capita) & 0.79 & 0.85 & 0.66 & 1.00 & & & & & & \\
\hline Real GDP growth & -0.10 & -0.20 & -0.16 & -0.16 & 1.00 & & & & & \\
\hline Population growth & -0.16 & -0.39 & -0.31 & -0.24 & 0.14 & 1.00 & & & & \\
\hline Open & 0.50 & 0.26 & 0.15 & 0.31 & 0.00 & -0.04 & 1.00 & & & \\
\hline Inflation & -0.23 & -0.25 & -0.24 & -0.26 & -0.06 & 0.07 & -0.09 & 1.00 & & \\
\hline Institutional quality & 0.54 & 0.58 & 0.45 & 0.64 & -0.05 & -0.13 & 0.27 & -0.23 & 1.00 & \\
\hline Corruption index & -0.58 & -0.67 & -0.58 & -0.68 & 0.18 & 0.19 & -0.25 & 0.28 & -0.67 & 1.00 \\
\hline
\end{tabular}


Appendix Table 3. Country Sample

\begin{tabular}{|c|c|c|c|c|c|}
\hline Afghanistan & Chile & Guyana & Mauritania & Rwanda & United Kingdom \\
\hline Albania & China & Haiti & Mauritius & St. Kitts and Nevis & Tanzania \\
\hline Algeria & Colombia & Honduras & Mexico & St. Lucia & United States \\
\hline Angola & Comoros & Hungary & Mongolia & \multicolumn{2}{|c|}{ Sao Tome and Princip Burkina Faso } \\
\hline Antigua and Barbuda & Congo, Rep. & Iceland & Moldova & Samoa & Uruguay \\
\hline Azerbaijan & Congo, Dem. Rep. & India & Morocco & Saudi Arabia & Uzbekistan \\
\hline Argentina & Costa Rica & Indonesia & Mozambique & Senegal & Venezuela, RB \\
\hline Australia & Croatia & Iran, Islamic Rep. & Oman & Serbia & Yemen, Rep. \\
\hline Austria & Cyprus & Iraq & Namibia & Seychelles & Zambia \\
\hline Bahamas, The & Czech Republic & Ireland & Nauru & Sierra Leone & \\
\hline Bahrain & Benin & Italy & Nepal & Singapore & \\
\hline Bangladesh & Denmark & Cote d'Ivoire & Netherlands & Slovak Republic & \\
\hline Armenia & Dominica & Jamaica & Vanuatu & Vietnam & \\
\hline Barbados & Dominican Republic & Japan & New Zealand & Slovenia & \\
\hline Belgium & Ecuador & Kazakhstan & Nicaragua & South Africa & \\
\hline Bhutan & Egypt, Arab Rep. & Jordan & Niger & Zimbabwe & \\
\hline Bolivia & El Salvador & Kenya & Nigeria & Spain & \\
\hline Bosnia and Herzegovina & Equatorial Guinea & Korea, Rep. & Norway & Sudan & \\
\hline Botswana & Ethiopia & Kuwait & Micronesia, Fed. Sts. & Suriname & \\
\hline Brazil & Eritrea & Kyrgyz Republic & Marshall Islands & Eswatini & \\
\hline Belize & Estonia & Lao PDR & Palau & Sweden & \\
\hline Solomon Islands & Fiji & Lebanon & Pakistan & Switzerland & \\
\hline Brunei Darussalam & Finland & Lesotho & Panama & Tajikistan & \\
\hline Bulgaria & France & Latvia & Papua New Guinea & Thailand & \\
\hline Myanmar & Gabon & Liberia & Paraguay & Togo & \\
\hline Burundi & Georgia & Libya & Peru & Tonga & \\
\hline Belarus & Gambia, The & Lithuania & Philippines & Trinidad and Tobago & \\
\hline Cambodia & Germany & Luxembourg & Poland & United Arab Emirates & \\
\hline Cameroon & Ghana & Madagascar & Portugal & Tunisia & \\
\hline Canada & Kiribati & Malawi & Guinea-Bissau & Turkey & \\
\hline Cabo Verde & Greece & Malaysia & Timor-Leste & Turkmenistan & \\
\hline Central African Republic & Grenada & Maldives & Qatar & Tuvalu & \\
\hline Sri Lanka & Guatemala & Mali & Romania & Uganda & \\
\hline Chad & Guinea & Malta & Russian Federation & Ukraine & \\
\hline
\end{tabular}

